\title{
Hematopoietic Differentiation from Embryonic Stem Cells
}

\author{
Yasuhisa Yokoyama, Hidekazu Nishikii and Shigeru Chiba \\ Department of Clinical and Experimental Hematology \\ Graduate School of Comprehensive Human Sciences \\ University of Tsukuba \\ Tsukuba, Ibaraki, \\ Japan
}

\section{Introduction}

Since the development of human embryonic stem cells (hESCs) in 1998, the potential of stem cell-based manufacturing of tissues or organs as a form of regenerative medicine has drawn broad interest because hESCs are pluripotent and can proliferate infinitely without losing their pluripotency (Thomson et al., 1998). More recently, induced pluripotent stem cells (iPSCs) were generated from human fibroblasts (Takahashi et al., 2007) as well as other cell sources (Stadtfeld and Hochedlinger, 2010), thus accelerating the goals of research to realize regenerative medicine.

Theoretically, any organ can be generated from ESCs, but the obstacles to manufacturing solid organs in vitro remain great. Solid organs such as kidney and liver require wellfunctioning three-dimensional structures consisting of different kinds of cells as well as formation of and communication with blood vessels. Considering this, hematopoietic progenitors or mature blood cells derived from ESCs may be among the most attractive applications because blood cells can operate as single cells without forming a multicellular structure. Here, we describe methods of hematopoietic differentiation from ESCs, particularly focusing on hESCs, and some problems that need to be resolved before hESCderived blood cells can be applied in the clinical setting.

\section{Summary of hematopoietic differentiation from murine ESCs}

\subsection{Hematopoietic progenitor differentiation from murine ESCs}

Since the days before and even after the development of hESCs, murine ESCs (mESCs) (Evans and Kaufman, 1981; Martin, 1981) have been a major tool in the study of differentiation of pluripotent stem cells into specialized cells. Although it is now recognized that there are a number of differences between mESCs and hESCs (Bhatia, 2007) and that it is indeed sometimes impossible to apply the differentiation protocols used in mESC experiments directly to those for hESCs, experiments using mESCs have provided us with important fundamentals for hESC research.

Methods developed to induce hematopoietic differentiation from mESCs can be classified into two categories: methods that use formation of embryoid bodies (EBs) (Doetschman et 
al., 1985) and those that use coculture with feeder cells (Gutierrez-Ramos and Palacios, 1992). In addition, genetic manipulation was also adopted for derivation of hematopoietic cells from mESCs (Kyba et al., 2002; Perlingeiro et al., 2001).

Embryoid bodies are cystic structures obtained by culturing ESC colonies in floating conditions in liquid or semisolid media. Hematopoietic differentiation in EBs is induced effectively by appropriate cytokine stimulation (Johansson and Wiles, 1995; Nakayama et al., 2000). In the early reports, only erythroid cells were detected in EBs (Doetschman et al., 1985; Lindenbaum and Grosveld, 1990). In 1991, it was reported that macrophages, neutrophils, and mast cells were also differentiated by semisolid culture of EBs in the presence of interleukin (IL)-3 (Wiles and Keller, 1991). The same group reported that bone morphogenic protein-4 (BMP-4) mediated formation of ventral mesoderm and hematopoietic precursors from EBs (Johansson and Wiles, 1995). A later study revealed that BMP-4 promoted generation of both myeloid and lymphoid precursors from EBs, and that this effect of BMP-4 was enhanced by addition of vascular endothelial growth factor (VEGF), although VEGF alone did not have a positive effect on hematopoietic differentiation from EBs (Nakayama et al., 2000).

Although EB formation is a useful method for generating hematopoietic cells with myelopoietic and lymphopoietic potentials, early methods using EB formation did not succeed in generating lymphoid progenitors. The first report of simultaneous generation of both myeloid and lymphoid lineages from mESCs adopted a coculture system. In this report, mESCs were cultured on OP9 feeder cells derived from calvaria of newborn (C57BL/6 $\times$ C3H)F2-op/op mice without addition of exogenous cytokines (Nakano et al., 1994). This simple culture system enabled mESCs to differentiate into hematopoietic progenitors that could differentiate into cells of various myeloid lineages as well as of B lymphocyte lineage. Thereafter, this cell line has been the standard feeder for hematopoietic differentiation not only from mESCs but also from hESCs. Other than OP9 cells, some cell lines, such as aorta-gonad-mesonephros (AGM) region-derived stromal cells (Weisel et al., 2006) or bone marrow-derived ST2 cells (Yamane et al., 2009), were also used but the OP9 cell-based method seems to be the most commonly used.

To advance the understanding of regulation of hematopoietic differentiation from mESCs, genetic manipulation of mESCs was frequently used. To demonstrate strictly that a single mESC-derived hematopoietic stem cell (HSC) could produce all lineages of mature blood cells in vivo, clonal analysis was performed using a gene transfer protocol (Perlingeiro et al., 2001). The chronic myeloid leukemia-associated oncogene bcr/abl was transferred to EBderived hematopoietic progenitors. The cells were further cultured on OP9 cells and thereafter cloned and transplanted into irradiated recipient mice. These cloned bcr/ablexpressing cells differentiated into multiple myeloid lineages as well as into $\mathrm{T}$ and $\mathrm{B}$ lymphocytes in vivo, indicating that definitive HSCs could be generated from EB-derived progenitors by transformation using bcr/abl.

A homeotic selector gene, HoxB4, proved to be a key factor in transforming EB-derived hematopoietic progenitors into definitive HSCs (Kyba et al., 2002). Like transformation by bcr/abl, ectopic expression of HoxB4 switched EB-derived primitive progenitors into definitive HSCs capable of long-term multilineage hematopoiesis. These approaches may provide further understanding of the mechanisms of HSC emergence from ESCs as well as from primordial cells during embryogenesis, although ESCs generated by means of genetic manipulation may confront further difficulties when clinical application is directly considered. 


\subsection{Lineage-specific differentiation of mature blood cells from murine ESCs}

In addition to HSC generation, lineage-specific differentiation of mature blood cells from mESCs has also been an important issue. Homogeneous populations of mESC-derived mature cells can be used in functional analyses and could form the basis of future hESCbased transfusion medicine. Studying the process of differentiation from mESCs to mature cells can lead to understanding of normal hematopoiesis as well. Similar to HSC induction, mature blood cells are usually generated by EB formation, coculture with feeder cells, or a combination of both. Lieber et al. described an effective three-step protocol for differentiating mESCs into mature neutrophils (Lieber et al., 2004). First, EBs were formed and cultured in Iscove modified Dulbecco medium (IMDM)-based fetal calf serum (FCS)containing medium for 8 days. Second, the EBs were disaggregated and replated onto OP9 cells in IMDM containing fetal bovine serum (FBS) and horse serum supplemented with oncostatin M, basic fibroblast growth factor (bFGF), IL-6, IL-11, and leukemia inhibitory factor (LIF) for 3 days. Finally, the cells were terminally differentiated on OP9 cells in IMDM containing platelet-depleted serum, granulocyte colony-stimulating factor (G-CSF), granulocyte-macrophage colony-stimulating factor (GM-CSF), and IL-6. During 7 to 14 days of terminal differentiation culture, $6 \times 10^{6}$ neutrophils were obtained from $8 \times 10^{4} \mathrm{mESCs}$. The purity of the mature neutrophils during this period reached $75 \%$ to $96 \%$. These mESCderived mature neutrophils expressed neutrophil-specific markers (Gr-1 and others) and contained gelatinase- and lactoferrin-positive granules. In the functional assays, mESCderived neutrophils showed superoxide production and chemotaxis comparable to those of normal neutrophils harvested from murine bone marrow. Interestingly, neutrophils differentiated from MEKK1-deficient mESCs displayed impaired migratory ability. This result indicated that $\mathrm{mESC}$-derived neutrophils could be used to study the genetic control of neutrophil differentiation and functions.

As regards the application of hESC-derived mature blood cells to transfusion medicine, the successful treatment of anemic mice by transfusion of mESC-derived erythroid progenitors was of great impact (Hiroyama et al., 2008). For the differentiation, mESCs were cultured on OP9 cells in IMDM-based medium with VEGF and insulin-like growth factor-II. On day 4, dexamethasone was added, and stem cell factor (SCF), erythropoietin (EPO), and IL-3 were substituted for the cytokines, although IL-3 could be omitted. After long-term culture in these conditions, immortalized erythroid cell lines were obtained. These mESC-derived erythroid progenitor lines expressed adult type $\alpha$ - and $\beta$-globins but did not express $\gamma^{-}, \varepsilon^{-}$, and $\zeta$-globins, indicating that they were adult-type erythroid cells. The erythroid progenitors could be differentiated in vitro into mature and enucleated cells. The erythroid progenitors could proliferate and differentiate in vivo, and when transplanted into anemic mice in which acute anemia was induced by hemolysis, the anemia ameliorated and the mice showed greater survival rates. Notably, no tumors were observed in the erythroid progenitor-transplanted mice for at least 6 months. These results are encouraging for future transfusion medicine using hESC-derived cells, although thorough investigation into the possibilities of tumorigenesis is needed.

Megakaryocytes and platelets were effectively produced by combination of EB formation and coculture with OP9 cells (Nishikii et al., 2008). After EB culture for 6 days, megakaryocyte progenitors expressing both c-kit and integrin $\alpha \mathrm{IIb}$ were sorted and further cultured on OP9 cells with TPO. For terminal differentiation, a mixture of TPO, IL-6, and IL11 was substituted for the cytokines after 3 days. Using this method, $2 \times 10^{5} \mathrm{mESC}$ produced $1 \times 10^{6}$ megakaryocyte progenitors on day 6 and $2.5 \times 10^{6}$ megakaryocytes on day 12 . After 2 
to 8 days of coculture with OP9 cells, the culture supernatants contained proplatelets and platelets. Electron microscopy analysis revealed that they contained alpha and dense granules, same as platelets from adult mice. However, these mESC-derived platelets showed low levels of glycoprotein (GP) Ibo expression, and in the in vitro thrombus formation model, mESC-derived platelets had impaired ability to participate in thrombogenesis, which is triggered by binding of von Willebrand factor to GPIb $\alpha$. Interestingly, shedding of GPIb $\alpha$ was prevented by addition of metalloproteinase inhibitors to the culture medium during differentiation, and this inhibition improved the thrombogenetic ability of the mESCderived platelets. The effect of inhibition of metalloproteinase activity was further examined using an in vivo model. Murine ESC-derived platelets with or without metalloproteinase inhibition were transfused into irradiated mice with severe thrombocytopenia. Addition of metalloproteinase inhibitors increased the percentage of mESC-derived platelets in the peripheral blood of the transfused mice.

A simple, well-established method is used for $\mathrm{T}$ cell differentiation from mESCs: coculture with OP9 cells ectopically expressing the Notch ligand Delta-like 1 (OP9-DL1) (Schmitt et al., 2004). On day 14 of the coculture, mESC-derived cells contained CD4 and CD8 doublenegative (DN) T lymphocyte progenitors, and on day 20, these cells contained doublepositive (DP) cells. When mESC-derived $\mathrm{CD} 25^{+}$DN progenitors were differentiated using deoxyguanosine-treated fetal thymic organ culture, they generated DP T cells and CD4 or CD8 single-positive (SP) T cells. Furthermore, when these thymic lobes containing mESCderived $\mathrm{T}$ cells were implanted under the skin of sublethally irradiated Rag2-null mice, which are devoid of $\mathrm{T}$ and $\mathrm{B}$ lymphocytes, reconstitution with mESC-derived CD4 or CD8 SP cells was observed. Infection of these mice with lymphocytic choriomeningitis virus (LCMV) induced LCMV-specific cytotoxic T lymphocyte activity, indicating that mESCderived mature $\mathrm{T}$ cells are capable of producing an effective antigen-specific immune response. As for B cells, coculture with OP9 cells induced B lineage development (Nakano et al., 1994), and this was enhanced by addition of Flt-3 ligand (FL) from day 5 of the coculture (Cho et al., 1999). After 4 weeks, more than $90 \%$ of the cells were CD45R ${ }^{+}$CD19+ B cells. In another report, knock down of PU.1 by small interfering RNA in CD34+ cells produced by EB formation induced $\mathrm{CD} 19+\mathrm{CD} 43{ }^{+} \mathrm{CD} 45^{+}$progenitor B (pro-B) cells (Zou et al., 2005). These mESC-derived pro-B cells produced precursor B (pre-B) cell colonies after a week of culture in a semisolid medium with IL-7 and IL-10, and a further 3-weeks culture enabled the pre-B cells to differentiate into mature B cells coexpressing immunoglobulin (Ig) M and CD19. These B cells produced by coculture with OP9 cells or by PU.1 knock down in EB cells showed up-regulation of CD80 and secretion of IgM by stimulation with lipopolysaccharide. Further detailed functional analyses, however, such as globulin class-switching, using mESC-derived B cells have so far not been performed.

\section{Hematopoietic stem cells derived from human ESCs}

Derivation of HSCs from hESCs, once successful, would have a great impact in both the clinical and basic research fields, given the wide range of potential applications. An unlimited amount of HSCs with various HLA and ABO blood types could be an ideal graft source in HSC transplantation, a starting material for manufacture of mature blood cells for blood transfusion, a gene transfer target for both clinical and experimental purposes, and so forth. 
Besides mESCs, EB formation and coculture with feeder cells are the two major strategies used to produce hematopoietic cells from hESCs, although most of the protocols developed for mESCs cannot be applied for hESCs without significant modifications (Bhatia, 2007). For example, LIF is a critical factor for mESCs to be maintained in an undifferentiated state, but hESC maintenance is not dependent on LIF. For the maintenance of hESCs, bFGF is used, whereas bFGF induces neural differentiation from mESCs (Ying et al., 2003). As for the markers of the undifferentiated state, specific embryonic antigen (SSEA)-3 and SSEA-4 are used for hESCs, while SSEA-1 is used for mESCs. For hematopoietic differentiation, longer cultures are needed for hESCs than for mESCs. Given that species-adjusted hESC-derived cell transplantation experiments are impossible, evaluation of hESC-derived HSCs largely depends on phenotypic assays, colony-forming assays, and in vivo transplantation models using animals such as immunodeficient mice. Non-obese diabetic severe combined immunodeficiency (NOD-SCID) mice have been widely used as the hosts for transplantation. For evaluation of hematopoietic ability, cells are transplanted into NODSCID mice and assayed by detection of SCID-repopulating cells (SRCs) (Ueda et al., 2000).

Kaufman et al. cultured hESCs on the murine bone marrow cell line S17 or the yolk sac endothelial cell line C166 in a medium containing FBS without any cytokines (Kaufman et al., 2001). This culture enabled hESCs to differentiate into progenitors capable of producing colonies with multiple hematopoietic lineages. As with somatic HSCs, these colony-forming cells were enriched in CD34+ ${ }^{+}$cells. Vodyanik et al. demonstrated that, as well as mESCs, hESCs could also be differentiated into $\mathrm{CD} 34^{+}$hematopoietic progenitors by coculture on OP9 cells (Vodyanik et al., 2005). When hESC-derived CD34+ cells were cultured on the murine bone marrow-derived cell line MS-5 in the presence of SCF, FL, IL-7, and IL-3, they could generate both myeloid and lymphoid cells.

Chadwick et al. formed EBs from hESCs and cultured them in the presence of SCF, FL, IL-3, IL-6, and G-CSF, with or without BMP-4 (Chadwick et al., 2003) and found that BMP-4 increased the number of hematopoietic progenitors from hESCs. The same group found that in these culture conditions including BMP-4, the primitive cells with ability to differentiate into both hematopoietic and endothelial cells would appear between day 7 and day 10 of the EB culture (Wang et al., 2004). These primitive cells expressed PECAM-1, Flk-1, and VEcadherin, but not CD45 (CD45-PFV). In a later report, they cultured CD45-PFV cells for 7 days in serum-containing medium supplemented with SCF, FL, G-CSF, IL-3, and IL-6 and differentiated them into CD45+ cells with SRC activity (Wang et al., 2005). These hESCderived $\mathrm{CD}_{4} 5^{+}$cells were transplanted directly into the femurs of sublethally irradiated NOD-SCID mice. Even at 8 weeks after transplantation, hESC-derived SRCs were detected, indicating that HSCs with reconstituting ability were obtained from the hESCs. But these hESC-derived HSCs could not repopulate in NOD-SCID mice when they were transplanted intravenously. Furthermore, hESC-derived HSCs showed lower levels of chimerism in the transplanted bone than did the somatic HSCs from human umbilical cord blood, and the same pattern was seen in the contralateral femur and other long bones. These results indicate that hESC-derived HSCs obtained by using this method are distinct from somatic HSCs in terms of the ability of proliferation and migration. Notably, the authors also mentioned that unlike in mESCs, ectopic expression of HoxB4 in hESCs accelerated proliferation of hematopoietic progenitors but had no effect on the repopulating capacity of hESC-derived cells.

The methods using coculture with feeder cells are also capable of generating hESC-derived HSCs. Tian et al. showed that hESCs cultured on S17 cells for 7 to 24 days differentiated into 
hematopoietic cells with SRC activity even when they were transplanted intravenously (Tian et al., 2006). They also performed a secondary transplantation from the bone marrow of the primary recipient of hESC-derived HSCs into secondary donor mice and confirmed the long-term repopulating ability of hESC-derived HSCs.

As mentioned above, hESCs can differentiate into hematopoietic cells with SRC activity, but this activity of hESC-derived cells remains low when compared with that of somatic HSCs such as cord blood CD $34^{+}$cells. We can thus conclude that no bona fide methods have been established that reproducibly generate true HSCs from hESCs. Recently, derivation of HSCs with higher SRC activity using a cell line derived from the AGM region was reported (Ledran et al., 2008). In that report, cell lines from the AGM region or fetal liver or primary cells from those organs were used as feeder cells. All hESC-derived hematopoietic cells differentiated on these feeders were capable of repopulating in immunodeficient mice when transplanted into the femurs of the recipient mice, and among the feeders the AGM-derived cell line AM20.1B4 was the best in terms of SRC activity of the hESC-derived cells. When this cell line was used, the chimerism of the hESC-derived cells in the peripheral blood of the recipient mice reached $16 \%$. Notably, this chimerism is higher than that in previous reports. Considering these results, it may be important to place hESCs in an environment that closely mimics a hematopoietic niche in order to obtain true HSCs from them.

\section{Mature blood cells derived from human ESCs}

\subsection{Neutrophils}

Neutrophil transfusion can be beneficial for severe neutropenic patients with congenital diseases or who have undergone chemotherapy if a sufficient number of neutrophils are transfused at appropriate intervals. The current blood donation system, however, is incapable of providing sufficient amounts of neutrophils on schedule, given that the half-life of neutrophils ex vivo is less than 10 hours and thus, that multiple transfusions per day are necessary to ensure effectiveness. Human ESC-derived neutrophils might provide a solution to these difficulties. They could also offer a new tool for drug discovery, drug toxicity monitoring, and so on. Recently, a method to obtain mature neutrophils with high purity from hESCs was developed (Yokoyama et al., 2009).

The culture system consisted of 2 phases: EB formation and OP9 coculture with different combinations of cytokines at each phase. For the formation of EBs, hESC colonies were detached from the mouse embryonic fibroblasts used as feeder cells to maintain the hESCs, using collagenase. The removed colonies were then cultured in the IMDM-based medium for HSC expansion (Suzuki et al., 2006) in a serum-free condition, which resulted in the initial formation of EBs within 24 hours. The resulting EBs were collected and cultured for 17 days in IMDM containing 15\% FBS supplemented with BMP-4, SCF, FL, IL-6/IL-6 receptor fusion protein (FP6), and TPO. For the preparation of feeder cells, irradiated OP9 cells were next plated onto gelatin-coated 6-well tissue culture plates at a density of $1.5 \times 10^{5}$ / well 24 hours before use. The EBs were dissociated into single cells and suspended in IMDM containing 10\% FBS and 10\% horse serum supplemented with a combination of SCF, FL, FP6, IL-3, and TPO. Then, up to $5 \times 10^{5}$ EB-derived cells were seeded in a well with the OP9 cell layer. After 7 days, floating cells were collected, suspended in IMDM containing 10\% FBS and G-CSF, and transferred onto the newly irradiated OP9 cells. Terminally differentiated cells were harvested 6 or 7 days later. 
As determined by morphology, most of the hESC-derived cells at day 7 of the final coculture with OP9 cells were myeloblasts and promyelocytes. On days 9 through 11, myeloblasts and metamyelocytes were dominant. On days 13 and $14,70 \%$ to $80 \%$ of the total cell population were differentiated mature neutrophils and the remaining $10 \%$ to $20 \%$, metamyelocytes. Transmission electron microscopic observation also revealed characteristic segmented nuclei and cytoplasmic granules. On days 13 and 14, Wright-Giemsa staining also revealed that up to $10 \%$ of the cells were monocyte- or macrophage-like cells, but no other cell lineages such as erythrocytes, megakaryocytes, or lymphocytes were observed throughout the culture. Thus, this differentiation protocol made it possible to obtain hESC-derived neutrophils at a high purity. These hESC-derived neutrophils were positively stained for myeloperoxidase, which is a major constituent of the primary granules of neutrophils. Biosynthesis of lactoferrin, which is a major constituent of the secondary granules, was analyzed by comparison of mRNA expressions of the hESC-derived cells with those of mature neutrophils from the peripheral blood and mononucleated cells from the bone marrow of healthy volunteers. Lactoferrin mRNA was expressed in hESC-derived cells as early as day 7 of the final induction culture on OP9 cells, peaked at day 10, and declined at days 13 and 14. This pattern was consistent with the documented pattern of lactoferrin biosynthesis (Rado et al., 1984). These patterns of morphological maturation and lactoferrin mRNA expression during the culture indicated that hESC-derived cells differentiated into mature neutrophils by a process similar to physiologic neutrophil production, and thus, this method could be used to investigate the differentiation process of neutrophils.
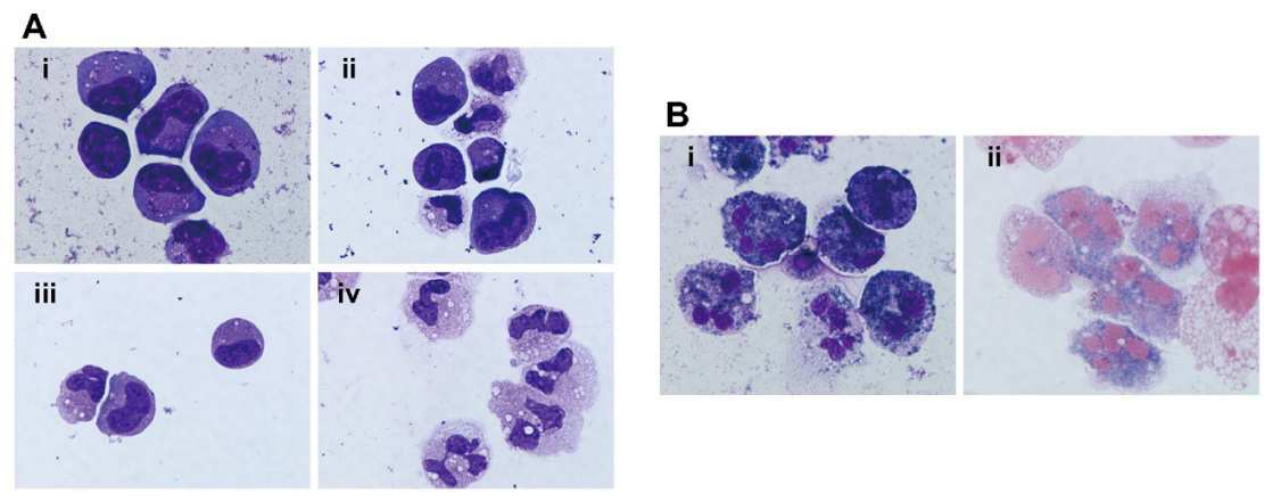

Fig. 1. Neutrophils derived from hESCs. (A) Wright-Giemsa staining of the hESC-derived cells at days 7 (i), 9 (ii), 11 (iii), and 13 (iv). (B) The hESC-derived neutrophils stained positive for myeloperoxidase and alkaline-phosphatase. This research was originally published in Blood. Yokoyama et al.. Derivation of functional mature neutrophils from human embryonic stem cells. Blood. 2009;113:6584-6592. (c) the American Society of Hematology.

Surface antigen expression of hESC-derived cells was analyzed at different time points by flow cytometry. The pattern of antigen expression was almost consistent with that of normal neutrophil differentiation, except for some G-CSF-related changes. Almost all the cells expressed the common blood cell antigen CD45 from days 7 through 13. A small population expressed the markers of immature hematopoietic cells such as CD34, CD117, and CD113 at 
day 7 but lost the expression by day 10. The common myeloid antigens CD33 and CD15 were highly expressed from days 7 through 13, whereas CD11b expression increased as maturation proceeded. CD13 is also a common myeloid antigen, but only fewer than $20 \%$ of

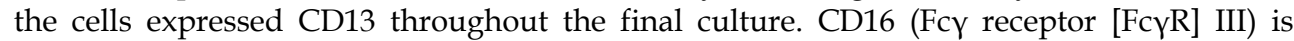
frequently used as the marker of mature neutrophils; it was already found on hESC-derived cells at day 7 and increased with maturation, which is consistent with the physiologic neutrophil maturation process. However, the proportion of $\mathrm{CD} 16^{+}$cells was lower than that of the morphology-defined mature neutrophils on day 13. Other Fcy receptors, CD32 (FcyRII) and CD64 (FcyRI), were also expressed on hESC-derived neutrophils. CD14 was expressed in $20 \%$ to $25 \%$ of the cells on days 10 and 13 . In normal peripheral blood, mature neutrophils express CD16 but not CD64 and CD14 (van de Winkel and Anderson, 1991; van Lochem et al., 2004), but some of the hESC-derived mature neutrophils expressed CD14, but not CD16, and most of the cells expressed CD64. This aberrant expression pattern is similar to that of the neutrophils harvested from healthy donors who received G-CSF (Carulli, 1997; Kerst et al., 1993) and of the neutrophils derived from bone marrow CD34+ cells in vitro by G-CSF stimulation (Kerst et al., 1993), and thus, hESC-derived neutrophils were thought to be also affected by G-CSF during the final culture.

The high purity and yield enabled subsequent functional analyses of the hESC-derived neutrophils. As seen in the expression of surface antigens, G-CSF used in the induction culture might affect the functions of hESC-derived neutrophils. Therefore, hESC-derived neutrophils were restimulated with G-CSF before the assay and compared with peripheral blood neutrophils with and without G-CSF stimulation.

Chemotaxis is the first step in innate immune system by neutrophils and important for neutrophils to be able to move to the inflammatory site effectively. Chemotaxis was analyzed using a modified Boyden chamber method (Harvath et al., 1980). In this method, reaction medium with or without chemotactic factor formyl-Met-Leu-Phe (fMLP) was placed into each well of a 24 -well plate, and a semipermeable membrane with 3.0- $\mu \mathrm{m}$ pores was placed into each well to divide the well into upper and lower sections. Neutrophils were added to the upper section and allowed to migrate from the upper to the lower side of the membrane. After incubation, the number of neutrophils on the lower side of the membrane was counted. The neutrophils that migrated to the lower side without fMLP were considered to have migrated randomly. This random migration of peripheral blood neutrophils was accelerated by G-CSF, but, despite the stimulation by G-CSF, the hESCderived neutrophils showed an extent of random migration that was only similar to that of the peripheral blood neutrophils without G-CSF stimulation. The number of cells that showed chemotaxis to fMLP was calculated by subtracting the number of migrated cells without fMLP from that of migrated cells with fMLP. This chemotaxis was not significantly different between hESC-derived neutrophils and peripheral blood neutrophils with or without G-CSF stimulation.

The next step in innate immune system by neutrophils is phagocytosis, and subsequently, killing of ingested microorganisms occurs mainly depending on superoxide production. We adopted a unique assay that simultaneously visualizes phagocytosis and superoxide production. Autoclaved baker's yeast was suspended in $0.5 \%$ nitroblue tetrazolium (NBT) solution $(0.5 \%$ NBT and $0.85 \%$ sodium chloride in distilled water). When these NBT-coated yeasts are ingested by neutrophils, the yeasts change their color from brown to purple or black because of reduction of NBT and formation of formazan in response to superoxide produced by neutrophils. We incubated these NBT-coated yeasts with hESC-derived and 
peripheral blood neutrophils. Ingested yeast cells that changed color in the cells were NBTreaction positive. The difference in the number of positive yeasts yeilded by the hESCderived neutrophils and peripheral blood neutrophils was not significant. G-CSF stimulation had no effect on the peripheral neutrophils in this assay.

Superoxide production by oxidative burst is the most important function for neutrophils to perform efficient bactericidal activity. In addition to the above-mentioned NBT reduction, we used dihydrorhodamine123 (DHR) to evaluate superoxide production. In the test, DHR was added to the neutrophil suspension with or without stimulation by phorbol myristate acetate (PMA), and rhodamine fluorescence from the oxidized DHR was detected by flow cytometry (Richardson et al., 1998). When DHR was added to the neutrophil suspensions, rhodamine-specific fluorescence was detected, indicating basal production of superoxide without PMA stimulation. Stimulation by PMA strongly increased rhodamine fluorescence in hESC-derived neutrophils and peripheral blood neutrophils, indicating that hESCderived neutrophils had sufficient capability of superoxide production and adequate response to stimulation.

Finally, we evaluated actual bactericidal activity in vitro using viable Escherichia coli (Decleva et al., 2006). Opsonized $E$ coli were added to the neutrophil suspension at a neutrophil/bacteria ratio of 2:1 or to the control medium. After 1 hour of incubation, the neutrophils were lysed, and the samples were added to molten tryptic soy broth with $1.5 \%$ agar and plated on dishes. The colonies derived from the surviving E coli were counted after overnight incubation. When the E coli were incubated with hESC-derived neutrophils and peripheral blood neutrophils with or without G-CSF stimulation, the numbers of the colonies were similarly reduced to approximately $40 \%$ those of the control, indicating that the hESC-derived neutrophils had bactericidal activity against $E$ coli comparable to that of normal neutrophils.

Generation of functional neutrophils using a feeder-free culture system was also reported by another group (Saeki et al., 2009). In this method, EBs were cultured in IMDM supplemented with FBS, insulin-like growth factor II, VEGF, SCF, FL, TPO, and G-CSF. After 3 days, the EBs were transferred onto gelatin-coated dish and cultured in the same medium as that of the EB culture. After 2 weeks of adherent culture on the gelatin-coated dish, sac-like structures (SLSs) emerged, and within a few days, round cells appeared in the sacs. These round cells had the potential to produce granulocyte, macrophage, or erythroid colonies. After 4 to 6 weeks of adherent culture, immature and mature myeloid cells were obtained, including mature neutrophils, although the purity of the mature neutrophils was relatively low (30\%-50\%). These hESC-derived neutrophils showed chemotaxis to fMLP and IL-8, phagocytosis of zymosan, and NBT-reduction. Interestingly, the authors of this report evaluated the chemotactic activity in vivo using a zymosan-induced air pouch inflammation model (Doshi et al., 2006). In this model, neutropenia was induced in immunodeficient NOD-SCID/ $/ c^{\text {null }}$ (NOG) mice by injection of 5-fluorouracil, and a subcutaneous air pouch was formed on the back of the NOG mice. After 3 days, $2 \times 10^{6} \mathrm{hESC}$-derived or human cord blood CD34-positive cells were transfused. Injection of both zymosan and IL-1 $\beta$ into the air pouch caused inflammation of the pouch, and accumulation of neutrophils in the pouch was observed. Among the massive murine neutrophils, hESC-derived neutrophils accounted for $0.54 \%$ of the total cells that were accumulated in the pouch. This percentage was the same as that for cord blood CD34 ${ }^{+}$cells. For the establishment of fundamentals for clinical application, in vivo analysis of neutrophil functions, especially the bactericidal activity and prolongation of survival of infected mice by neutrophil transfusion, is needed. 


\subsection{Erythrocytes}

Adult-type erythrocytes derived from hESCs could be a new and ideal transfusion source if large-scale production can be achieved, given that they could be free from infectious organisms. Furthermore, hESC-derived erythrocytes from rare blood-type donors might resolve the difficulty of availability of such types of RBCs.

In normal human erythroid development, the expression pattern of hemoglobin subunits in erythrocytes changes according to the developmental stage. In primitive yolk sac erythropoiesis, embryonic-type $\zeta$ - and $\varepsilon$-globin are expressed. In definitive erythropoiesis, $\zeta$-globin and $\varepsilon$-globin switch to fetal-type $\alpha$-globin and $\gamma$-globin, respectively, and $\gamma$-globin further switches to adult-type $\beta$-globin (Peschle et al., 1985). When evaluating erythrocytes derived from hESCs, in addition to the efficiency of the induction culture, it is important to examine the globin expression pattern to determine the erythrocyte type.

As described in section 3, culturing EBs in the presence of SCF, FL, IL-3, IL-6, G-CSF, and BMP-4 accelerates the generation of hematopoietic progenitors (Chadwick et al., 2003), and when VEGF was added to these basal cytokines, both the number and the frequency of erythroid colonies derived from the EBs were augmented (Cerdan et al., 2004). Evaluation of globin expression by detection of mRNA of each globin revealed that the cells from EBs treated with only basal cytokines expressed only $\varepsilon$-globin, but addition of VEGF to the basal cytokines promoted expression of both $\varepsilon$ - and $\zeta$-globins. $\beta$-globin expression was not proven in either culture condition. Thus, the erythropoiesis in the EBs cultured with this combination of cytokines was thought to recapitulate primitive erythropoiesis with embryonic globin expression. However, the erythrocytes picked up from the EB-derived erythroid colonies in a semisolid culture expressed $\beta$-globin in addition to $\varepsilon$-globin, but not $\zeta$-globin, indicating the possibility of globin switch during the colony-formation culture. Expression of embryonic and fetal globins, but not adult $\beta$-globin in hESC-derived erythrocytes was also reported by different groups (Chang et al., 2006; Olivier et al., 2006).

Other groups showed successful expression of $\beta$-globin in hESC-derived erythrocytes. Ma et al. developed an efficient method of inducing erythrocytes using coculture with feeder cells (Ma et al., 2007; Ma et al., 2008). In this method, the hESC colonies were cultured on irradiated primary murine fetal liver stromal cells without any cytokines. At days 11 to 12, hESC-derived cells formed SLSs containing hematopoietic cobblestone-like cells. On day 14, $1 \times 10^{4}$ original hESCs had given rise to $1 \times 10^{6}$ total cells including $5 \times 10^{3}$ cobblestone-like cells. When the mixture of stromal cells and all hESC-derived cells were prepared as a single cell suspension and cultured in a semi-solid medium with EPO, SCF, IL-3, IL-6, TPO, and GCSF, they generated mainly erythroid colonies including erythroid bursts, although approximately $25 \%$ were non-erythroid colonies. Erythroid bursts accounted for about $5 \%$ of the total colonies, and each large erythroid burst contained approximately $2 \times 10^{5}$ erythroid cells. Importantly, about $60 \%$ of the hemoglobin-containing erythroid cells in each erythroid burst derived from hESC after 12-day co-culture on murine fetal liver stromal cells expressed adult $\beta$-globin, and the proportion reached nearly $100 \%$ when the coculture was extended to 18 days. In contrast, the proportion of $\varepsilon$-globin-expressing erythroid cells in each erythroid burst decreased from $100 \%$ to $60 \%$. Globin switch could also be observed when the day 12-erythroid bursts were transferred to a suspension culture for an additional 6 days; the expression of $\varepsilon$-globin decreased, whereas $\beta$-globin expression increased to about $100 \%$, and, notably, $\beta$-globin-expressing enucleated RBCs were observed. The hESC-derived erythroid cells could function as oxygen carriers showing oxygen dissociation curves similar to those of human cord blood RBCs, although their curves were left-shifted when compared 
to those of adult peripheral blood RBCs. The hESC-derived erythroid cells had higher glucose-6-phosphate dehydrogenase activity than did the adult peripheral blood RBCs.

$\mathrm{Lu}$ et al. showed two methods of producing erythrocytes using hemangioblasts derived from hESCs as starting materials: one, the massive production of nucleated erythrocytes without adult $\beta$-globin expression, and the other, induction of enucleation of hESC-derived erythrocytes with some $\beta$-globin expression ( $\mathrm{Lu}$ et al., 2008). By the method for massive production, they generated $10^{10}$ to $10^{11}$ erythrocytes from one 6-well plate of hESCs. In the first step, EBs were formed and cultured in serum-free medium containing BMP-4, VEGF, and bFGF. After 48 hours, half the medium was exchanged for fresh medium with the same cytokines and additional SCF, TPO, and FL, and cultured for a further 36 hours. In the second step, EBs were then dissociated into single cells, which were cultured for 10 days in blast-colony growth medium (BGM) consisting of IMDM, 1.0\% methylcellulose, bovine serum albumin, insulin, iron-saturated transferrin, GM-CSF, IL-3, IL-6, G-CSF, EPO, SCF, VEGF, and BMP-4. Dependent on the hESC lines, TPO and FL were added to the cytokine combination. This culture condition induced and expanded the hESC-derived hemangioblasts that had been described in a previous report (Lu et al., 2007). To optimize the method, they used a fusion protein consisting of HoxB4 and triple protein-transduction domains (tPTD-HoxB4). The PTD used here was a modified form of PTD embedded in the transactivator of transcription protein of the human immunodeficiency virus (Ho et al., 2001; Lu et al., 2007). Maximum efficiency was achieved when tPTD-HoxB4 and bFGF were added to the BGM. In the third step, equal volumes of BGM containing additional EPO were added to the existing BGM, and the cells were further cultured and differentiated into erythroid cells for 5 days. The erythroid cells were then transferred to serum-free medium containing SCF, EPO, and $0.5 \%$ methylcellulose, and expanded for 7 days. In the final step, for the purification of the erythroid cells, the resulting cells were plated in tissue culture flasks overnight to allow nonerythroid cells to attach to the flasks, and the nonadherent cells were collected. By this method, numerous erythroid cells (1010 to $10^{11}$ cells from one 6-well plate of hESCs) could be obtained; however, these hESC-derived erythroid cells were nucleated and contained embryonic $\zeta$ - and $\varepsilon$-globins, and fetal ${ }^{G} \gamma$-globin, but neither fetal ${ }^{A} \gamma$-globin nor adult $\beta$-globin. Nevertheless, the hESC-derived erythroid cells showed an oxygen equilibrium curve comparable to that of normal adult RBCs.

A modification of this method allowed enucleated hESC-derived erythrocytes with adult $\beta$ globin to be obtained. The protocols in the first step and up to day 7 in the second step were the same. After 7 days of culture in the second step, the cells were cultured in serum-free medium containing bovine serum albumin, inositol, folic acid, transferrin, insulin, ferrous nitrate, and ferrous sulfate, and supplemented with hydrocortisone, SCF, IL-3, and EPO. After 7 days, SCF and IL-3 were removed. In these conditions, $10 \%$ to $30 \%$ of the hESCderived erythrocytes were enucleated. Importantly, considering that the hESCs were maintained without feeder cells, the enucleated erythrocytes were generated in completely feeder-free conditions. By this method, however, hESCs showed expansion of only 30- to 50fold. Furthermore, even after enucleation, the hESC-derived erythrocytes expressed mainly embryonic $\zeta$ - and $\varepsilon$-globins, and fetal $\gamma$-globin, but not $\beta$-globin. However, survival and enucleation of the erythrocytes were enhanced when they were cocultured on OP9 cells, and long-term culture of the cells induced adult $\beta$-globin expression from $0 \%$ at day 17 to $16 \%$ at day 28, indicating the potential of globin switch of hESC-derived erythrocytes.

Dependent on the methods, the expression patterns of the hemoglobin subunits were different. Comparison of the methods would be useful to understanding the mechanisms of 
erythroid development and globin switch. If hESC-derived fetal erythrocytes could be successfully changed to adult erythrocytes and high efficiency achieved, it would open up the way to clinical use.
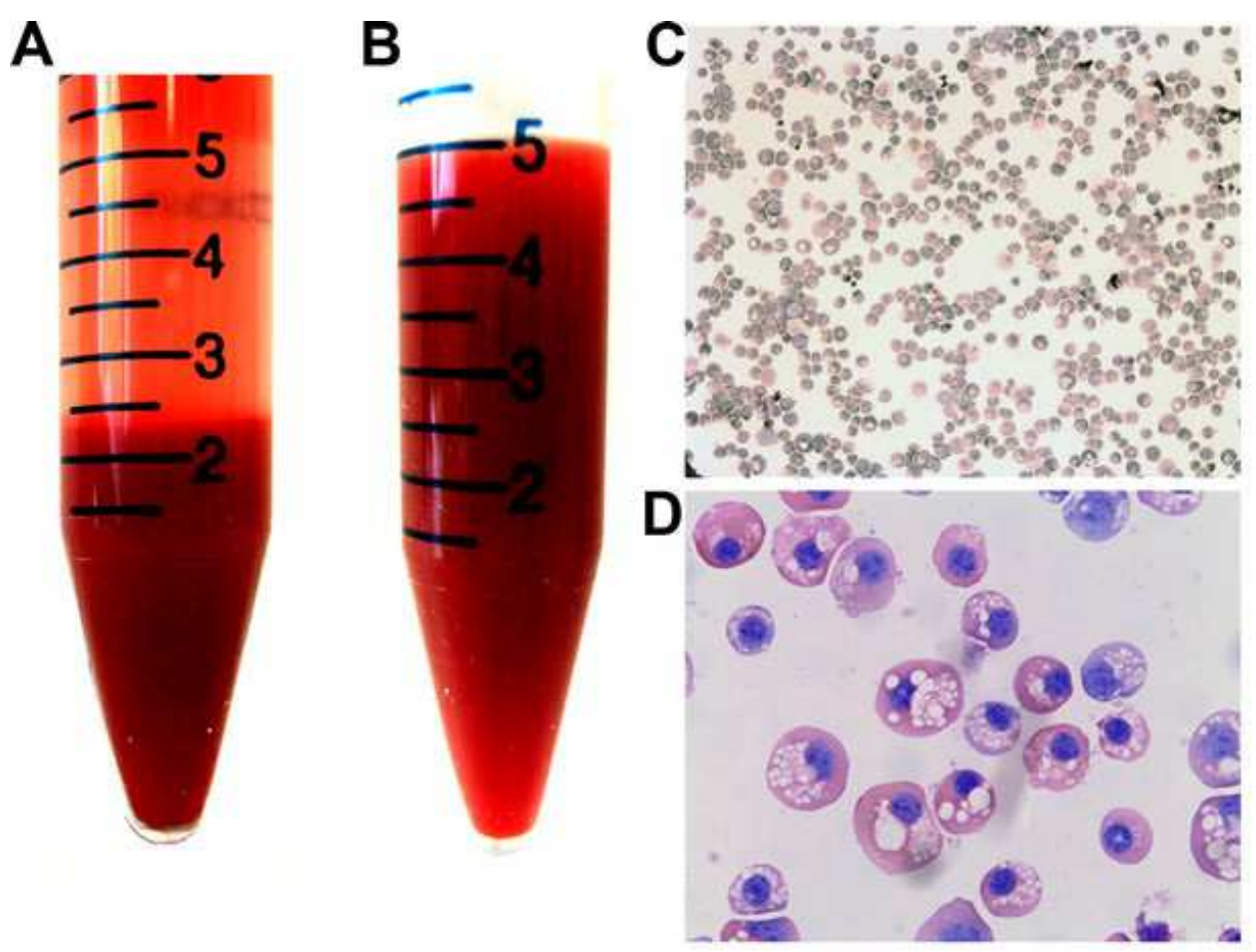

Fig. 2. Erythrocytes derived from hESCs. (A) Erythrocytes derived from $2 \times 10^{6}$ hESCs. (B) Suspension of erythrocytes from panel A in equivalent hematocrit of human whole blood. (C, D) Wright-Giemsa staining of hESC-derived erythrocytes. Original magnification, C: $\times 200$, D: $\times 1000$. This research was originally published in Blood. Lu et al.. Biologic properties and enucleation of red blood cells from human embryonic stem cells. Blood. 2008;112:44754484. (c) the American Society of Hematology.

\subsection{Megakaryocytes and platelets}

Platelet derivation from hESCs is also of concern for transfusion medicine. Platelets can be stored for only 3 to 4 days, and more donors are needed to secure sufficient amounts of platelet concentrates than are needed for RBCs. Two groups so far reported specific methods for megakaryocyte/platelet derivation from hESCs, and both used coculture with feeder cells (Gaur et al., 2006; Takayama et al., 2008). In the first report, small clumps of hESCs were cultured on OP9 cells in the presence of $100 \mathrm{ng} / \mathrm{mL}$ TPO. The cells were transferred onto fresh OP9 cells on days 7 and 11 . After 15 to 17 days of culture, $20 \%$ to $60 \%$ of the hESC-derived cells were positive for both CD41a and CD42b, which are representative markers of the megakaryocyte lineage. In this culture, $1 \times 10^{5}$ starting hESCs yielded 1 to

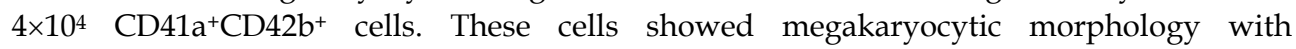


polyploidy. The hESC-derived megakaryocytes showed substantial increase of fibrinogenbinding capacity compared to baseline in response to thrombin receptor-activating agonists or adenosine di-phosphate. This result indicated the presence of appropriate inside-out signaling of integrin aIIb $\beta 3$ in hESC-derived megakaryocytes, which controls affinity and avidity of integrin aIIb $\beta 3$ for fibrinogen. Moreover, when hESC-derived megakaryocytes were plated on fibrinogen-coated glass cover slips, they showed extensive lamellipodia formation, F-actin formation, and vinculin localization, indicating proper outside-in signaling of integrin aIIb $\beta 3$. However, these apparently functional megakaryocytes rarely differentiated to proplatelets. These data imply that terminal differentiation to mature platelets might not be observed in this culture system. On the other hand, Takayama et al. confirmed the first report of the derivation of megakaryocytes from hESC using coculture with OP9 cells, and developed a new method of generating megakaryocytes capable of releasing platelets (Takayama et al., 2008). Coculture of hESCs on either C3H10T1/2 or OP9 cells without transfer to new feeders for 2 weeks led to emergence of SLSs. Addition of VEGF to the culture medium increased the number of the SLSs. These SLSs contained hematopoietic progenitors with multilineage colony-forming potential, and those progenitors could be further differentiated into mature proplatelet-forming megakaryocytes when transferred onto new feeder cells and cultured in the presence of TPO for an additional 7 to 9 days. $\mathrm{CD} 41 \mathrm{a}^{+} \mathrm{CD} 42 \mathrm{~b}^{+}$platelets were then detected in the culture supernatants. The maximum yield was achieved when the medium was supplemented with SCF and heparin in addition to TPO, resulting in approximately $5 \times 10^{6}$ platelets produced from $10^{5}$ hESCs. The hESC-derived platelets had appropriate inside-out and outside-in signaling of integrin aIIb $\beta 3$. This method is expected to be useful for studies of the developmental mechanisms and functions of megakaryocytes and platelets, and for transfusion medicine, although extreme improvement in the efficiency of platelet generation from hESCs is needed.

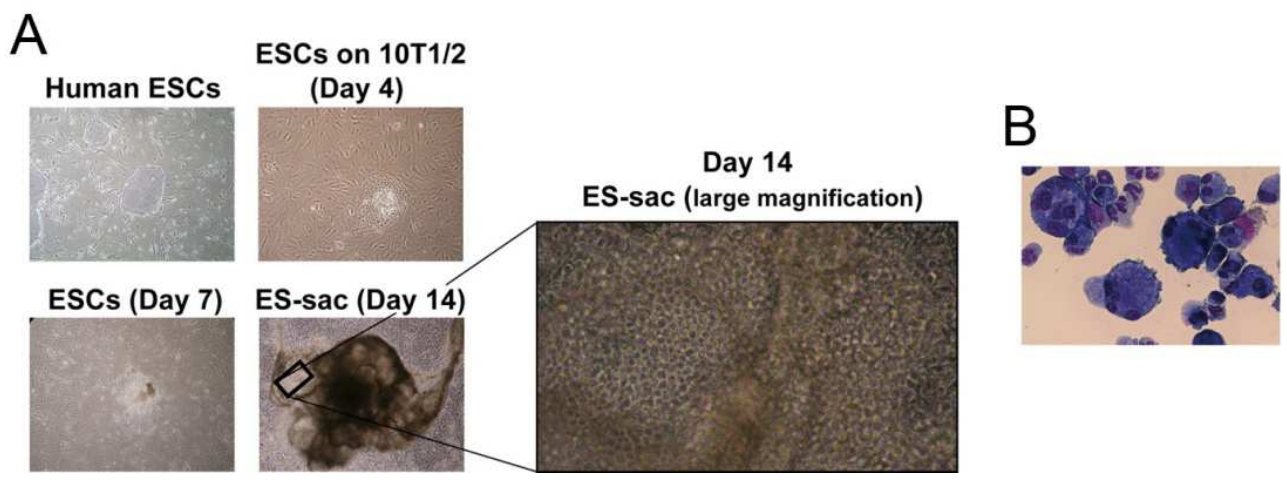

Fig. 3. Sac-like structures and megakaryocytes derived from hESCs. (A) Sac-like structures with distinct morphology. They contained hematopoietic progenitors. (B) Megakaryocytes derived from hESC. This research was originally published in Blood. Takayama et al. Generation of functional platelets from human embryonic stem cells in vitro via ES-sacs, VEGF-promoted structures that concentrate hematopoietic progenitors. Blood. 2008;111:52985306. (c) the American Society of Hematology. 


\subsection{Natural killer cells}

Natural killer (NK) cells have cytotoxic enzymes and play a major role in innate immunity. They also have antitumor activity, and the possibility of safe and efficaciously adoptive immunotherapy using NK cells has been shown in the setting of allogeneic hematopoietic stem cell transplantation or studies of NK cell transfusion for malignancies (Ljunggren and Malmberg, 2007; Miller et al., 2005; Ruggeri et al., 2002). Derivation of NK cells with antitumor activity from hESCs could be a possible means of immunotherapy. The most functional hESC-derived NK cells so far were generated by sequential coculture on different feeder cells (Woll et al., 2005; Woll et al., 2009). Firstly, hESCs were cultured on S17 or a murine bone marrow stromal cell line M210-B4 for 17 to 20 days. After the first coculture, $\mathrm{CD} 34^{+} \mathrm{CD} 45^{+}$cells were sorted and transferred to a murine fetal liver-derived stromal cell line, AFT024, and cocultured in medium containing human AB blood-type serum with a cytokine cocktail consisting of IL-3, SCF, IL-15, FL, and IL-7. At 3 to 5 weeks of culture, approximately $70 \%$ of the hESC-derived cells were CD45- and CD56-positive NK cells, with expression of receptors typically found on adult NK cells such as CD16, CD94, NKp46, and killer-cell Ig-like receptors (KIR or CD158). Interestingly, hESC-derived NK cells showed higher cytolytic activity against various tumor and leukemia cell lines than did NK cells derived from cord blood progenitors under the same conditions. Higher antileukemic activity in vivo with hESC-derived NK cells was also demonstrated in a mouse model for human leukemia using the human erythroleukemia cell line K562. These results indicate that hESC-derived NK cells are potentially a good source for immunotherapy.

\section{5 $\mathrm{T}$ and $\mathrm{B}$ lymphocytes and other lineages}

$\mathrm{T}$ and $\mathrm{B}$ cells have central roles in acquired immunity, but derivation of these cells from hESCs could be more difficult than that of cells of other lineages. As described in section 2 . 2, mESCs can be easily differentiated into T cells using OP9-DL1 cells. However, Martin et al. reported that hESC-derived $\mathrm{CD}_{3} 4^{+}$progenitors could not be differentiated into the T-cell lineage in vitro even by co-culture with OP9-DL1 cells or by fetal thymic organ culture (Martin et al., 2008). The first successful specific derivation of mature T cells from hESCs was achieved by an in vivo procedure using SCID-hu mice (Galic et al., 2006). The SCID-hu mice were constructed by insertion of human fetal thymus and liver under the renal capsule of SCID mice, and provide the environment for T lineage differentiation (Akkina et al., 1994; McCune et al., 1988). Human ESC-derived CD34 ${ }^{+}$or $\mathrm{CD}_{4} 4-\mathrm{CD} 133^{+}$hematopoietic progenitors, obtained by coculture with OP9 cells for 7 to 14 days, were injected into thymus/liver implants in sublethally irradiated SCID-hu mice. After 3 to 5 weeks, biopsy of the thymus/liver implants demonstrated repopulation of hESC-derived cells in the implants accounting for up to $6.2 \%$ of the total cells. Phenotypic analysis revealed differentiation of hESCs into immature $\mathrm{CD} 4{ }^{+} \mathrm{CD} 8{ }^{+} \mathrm{T}$ cells and mature $\mathrm{CD} 4{ }^{+} \mathrm{CD} 8-$ and $\mathrm{CD} 8{ }^{+} \mathrm{CD} 4-\mathrm{T}$ cells. Later, the same group modified the methods and adopted EB formation instead of coculture with OP9 cells (Galic et al., 2009), and they showed normal V(D)J recombination during differentiation of hESC-derived T cells and CD25 expression on the cells in response to stimulation. However, complicated and cumbersome in vivo procedures, particularly the use of human fetal thymus and liver, obviously hamper the further progress of the study of hESC-derived T-cell development.

Contrary to the previous report by Martin et al., Timmermans et al. reported an in vitro method of T cell differentiation using coculture with OP9-DL1 (Timmermans et al., 2009). In 
this method, hESCs were cocultured on OP9 cells. After 10 to 12 days, endothelium-lined cell clumps emerged that resembled the hESC-derived SLSs described in Takayama's method of megakaryocyte differentiation. These structures were transferred onto OP9-DL1 cells and cultured in medium supplemented with FL, IL-7, and SCF. After 14 days of coculture on OP9-DL1 cells, CD4 SP cells and CD4 CD8 $\alpha \alpha$ DP cells were detected within the cytoplasmic $\mathrm{CD} 3 \varepsilon^{+} \mathrm{CD}^{+}$cell population. After 21 days, CD4 CD8 $\alpha \beta$ DP cells appeared, and on day 28 , DP cells accounted for $25 \%$ of the cells. After 30 days of culture, $15 \%$ to $50 \%$ of hESC-derived cells were T lineage cells expressing surface CD3 and TCR $\alpha \beta$. In addition to the $\mathrm{CD} 3^{+} \mathrm{TCR} \alpha \beta^{+}$cells, $\mathrm{CD} 3^{+} \mathrm{TCR} \gamma \delta^{+}$cells also emerged. These results suggested that hESCderived $\mathrm{T}$ cells differentiated phenotypically in a way similar to that in thymic development. In response to stimulation, hESC-derived $\mathrm{T}$ cells showed a 2,500-fold increase, and all surface $\mathrm{CD}^{+} \mathrm{T}$ cells had the mature $\mathrm{CD} 27^{+} \mathrm{CD} 1 \mathrm{a}^{-}$phenotype. Restimulation of the expanded $\mathrm{T}$ cells induced interferon- $\gamma$ production. These results indicated that phenotypically and functionally mature $\mathrm{T}$ cells could be generated from hESCs, although detailed functional analyses have yet to be performed.

B cell differentiation from hESCs is also challenging compared with that of other lineages. No effective methods for achieving B cell differentiation from hESCs have so far been devised. Martin et al. reported that hESC-derived CD34+ hematopoietic progenitors lacked B lineage differentiation capability when cocultured with MS-5 cells that support B cell differentiation from cord blood CD34+ progenitors (Martin et al., 2008). Thus, an additional cue is required to establish an environment sufficient for B cell differentiation, in addition to the cytokines and feeders that have been used so far. Given the success in B cell differentiation from mESCs, differences between mESCs and hESCs or species specificities of the feeder cell-expressed proteins may explain this hurdle.

Other lineages of blood cells, such as macrophages (Anderson et al., 2006) and dendritic cells (Slukvin et al., 2006), can also be generated from hESCs. As described in this section, hESC-derived mature blood cells including neutrophils, erythrocytes, megakaryocytes, and NK cells are commonly very similar to their normal counterparts in morphology, phenotype, and function. Therefore, if sufficient amounts of mature blood cells derived from hESCs can be obtained, they can be expected to be used for a variety of purposes, for example, as substitutes for normal blood cells for in vitro drug screening and as blood transfusion sources.

\section{Future directions}

Coculture with feeder cells and EB formation are the two major strategies for hematopoietic differentiation from hESCs commonly used to generate both progenitors and mature blood cells. However, no methods for generating bona fide HSCs from hESCs have yet been established, despite the fact that feeder cells derived from bone marrow, fetal liver, and AGM should provide a hematopoietic microenvironment similar to the physiologic one. As regards the preparation of an ideal microenvironment for inducing HSCs from hESCs, the combined use of an in vitro culture system with an animal body may prove a powerful method. Recently, a sensational report of the generation of rat pancreas in mouse was published (Kobayashi et al., 2010). Injection of rat wild-type iPSCs into blastocysts of a Pdx1null mouse, which is devoid of pancreas and dies soon after birth, resulted in the development of a compensatory pancreas entirely derived from rat iPSCs. This result indicated that when a developmental niche for a certain organ is empty, pluripotent stem 
cell-derived cells can occupy the niche and compensate for the missing organ. Considering application of this finding for hematopoiesis, it may be possible to obtain pluripotent stem cell-derived HSCs using a mouse that is devoid of HSCs, for example, GATA2- (Tsai et al., 1994), SCL/Tal1- (Porcher et al., 1996), Runx1/AML1- (Okuda et al., 1996), or Notch1(Kumano et al., 2003) null mice. This approach of interspecific blastocyst complementation might contribute to overcoming the issue of yield, which still represents a high barrier to reaching clinical applications. If large animals, such as pigs, without hematopoietic ability become available, injection of human ESCs or iPSCs into their blastocysts might make it possible to obtain massive amounts of human HSCs and mature blood cells, although contamination with xenogeneic constituents is still a problem, and ethical arguments must be addressed before proceeding to the generation of human-animal hybrid embryos, particularly given that human cells could be differentiated into mature cells other than blood cells in the animal.

To achieve magnitudes of increase in cell number yields, which is necessary for virtually all the protocols hitherto reported, one potential goal is generation of progenitor cell lines that can proliferate infinitely and produce mature blood cells. As described in section 2. 2, mESC-derived erythroid progenitor lines could differentiate into functional mature red blood cells both in vitro and in vivo and ameliorate anemia in mice (Hiroyama et al., 2008). Although these erythroid progenitor lines were generated by coculturing with feeder cells under cytokine stimulation, genetic manipulation of hESCs or their progenies can also be considered. Gene manipulation has a risk of causing tumorigenesis; however, this concern is much smaller in the case of RBCs and platelets, given that these are unnucleated cells.

With the accumulated findings of hematopoietic differentiation from hESCs, hESC-derived HSCs and mature blood cells are now or will soon be good resources for functional analyses, drug-screening tests, research into the differentiation process, and so forth. Remarkable progresses in this field are continuously being made, which is encouraging for the achievement of clinical application of hESC-derived blood cells in the not-too-distant future.

\section{References}

Akkina, R. K.; Rosenblatt, J. D.; Campbell, A. G.; Chen, I. S. \& Zack, J. A. (1994). Modeling human lymphoid precursor cell gene therapy in the SCID-hu mouse. Blood, Vol. 84, No. 5, (Sep 1 1994) 1393-1398, 0006-4971 (Print) 0006-4971 (Linking)

Anderson, J. S.; Bandi, S.; Kaufman, D. S. \& Akkina, R. (2006). Derivation of normal macrophages from human embryonic stem (hES) cells for applications in HIV gene therapy. Retrovirology, Vol. 3, No. 2006) 24, 1742-4690 (Electronic) 1742-4690 (Linking)

Bhatia, M. (2007). Hematopoietic development from human embryonic stem cells. Hematology Am Soc Hematol Educ Program, Vol. No. 2007) 11-16, 1520-4391 (Print) 1520-4383 (Linking)

Carulli, G. (1997). Effects of recombinant human granulocyte colony-stimulating factor administration on neutrophil phenotype and functions. Haematologica, Vol. 82, No. 5, (Sep-Oct 1997) 606-616, 0390-6078 (Print) 0390-6078 (Linking)

Cerdan, C.; Rouleau, A. \& Bhatia, M. (2004). VEGF-A165 augments erythropoietic development from human embryonic stem cells. Blood, Vol. 103, No. 7, (Apr 12004 ) 2504-2512, 0006-4971 (Print) 0006-4971 (Linking) 
Chadwick, K.; Wang, L.; Li, L.; Menendez, P.; Murdoch, B.; Rouleau, A. \& Bhatia, M. (2003). Cytokines and BMP-4 promote hematopoietic differentiation of human embryonic stem cells. Blood, Vol. 102, No. 3, (Aug 1 2003) 906-915, 0006-4971 (Print) 0006-4971 (Linking)

Chang, K. H.; Nelson, A. M.; Cao, H.; Wang, L.; Nakamoto, B.; Ware, C. B. \& Papayannopoulou, T. (2006). Definitive-like erythroid cells derived from human embryonic stem cells coexpress high levels of embryonic and fetal globins with little or no adult globin. Blood, Vol. 108, No. 5, (Sep 1 2006) 1515-1523, 0006-4971 (Print) 0006-4971 (Linking)

Cho, S. K.; Webber, T. D.; Carlyle, J. R.; Nakano, T.; Lewis, S. M. \& Zuniga-Pflucker, J. C. (1999). Functional characterization of B lymphocytes generated in vitro from embryonic stem cells. Proc Natl Acad Sci U S A, Vol. 96, No. 17, (Aug 17 1999) 97979802, 0027-8424 (Print) 0027-8424 (Linking)

Decleva, E.; Menegazzi, R.; Busetto, S.; Patriarca, P. \& Dri, P. (2006). Common methodology is inadequate for studies on the microbicidal activity of neutrophils. J Leukoc Biol, Vol. 79, No. 1, (Jan 2006) 87-94, 0741-5400 (Print) 0741-5400 (Linking)

Doetschman, T. C.; Eistetter, H.; Katz, M.; Schmidt, W. \& Kemler, R. (1985). The in vitro development of blastocyst-derived embryonic stem cell lines: formation of visceral yolk sac, blood islands and myocardium. J Embryol Exp Morphol, Vol. 87, No. (Jun 1985) 27-45, 0022-0752 (Print) 0022-0752 (Linking)

Doshi, M.; Koyanagi, M.; Nakahara, M.; Saeki, K. \& Yuo, A. (2006). Identification of human neutrophils during experimentally induced inflammation in mice with transplanted CD34+ cells from human umbilical cord blood. Int J Hematol, Vol. 84, No. 3, (Oct 2006) 231-237, 0925-5710 (Print) 0925-5710 (Linking)

Evans, M. J. \& Kaufman, M. H. (1981). Establishment in culture of pluripotential cells from mouse embryos. Nature, Vol. 292, No. 5819, (Jul 9 1981) 154-156, 0028-0836 (Print) 0028-0836 (Linking)

Galic, Z.; Kitchen, S. G.; Kacena, A.; Subramanian, A.; Burke, B.; Cortado, R. \& Zack, J. A. (2006). T lineage differentiation from human embryonic stem cells. Proc Natl Acad Sci U S A, Vol. 103, No. 31, (Aug 1 2006) 11742-11747, 0027-8424 (Print) 0027-8424 (Linking)

Galic, Z.; Kitchen, S. G.; Subramanian, A.; Bristol, G.; Marsden, M. D.; Balamurugan, A.; Kacena, A.; Yang, O. \& Zack, J. A. (2009). Generation of T lineage cells from human embryonic stem cells in a feeder free system. Stem Cells, Vol. 27, No. 1, (Jan 2009) 100-107, 1549-4918 (Electronic) 1066-5099 (Linking)

Gaur, M.; Kamata, T.; Wang, S.; Moran, B.; Shattil, S. J. \& Leavitt, A. D. (2006). Megakaryocytes derived from human embryonic stem cells: a genetically tractable system to study megakaryocytopoiesis and integrin function. J Thromb Haemost, Vol. 4, No. 2, (Feb 2006) 436-442, 1538-7933 (Print) 1538-7836 (Linking)

Gutierrez-Ramos, J. C. \& Palacios, R. (1992). In vitro differentiation of embryonic stem cells into lymphocyte precursors able to generate $\mathrm{T}$ and B lymphocytes in vivo. Proc Natl Acad Sci U S A, Vol. 89, No. 19, (Oct 1 1992) 9171-9175, 0027-8424 (Print) 0027-8424 (Linking)

Harvath, L.; Falk, W. \& Leonard, E. J. (1980). Rapid quantitation of neutrophil chemotaxis: use of a polyvinylpyrrolidone-free polycarbonate membrane in a multiwell assembly. J Immunol Methods, Vol. 37, No. 1, 1980) 39-45, 0022-1759 (Print) 00221759 (Linking) 
Hiroyama, T.; Miharada, K.; Sudo, K.; Danjo, I.; Aoki, N. \& Nakamura, Y. (2008). Establishment of mouse embryonic stem cell-derived erythroid progenitor cell lines able to produce functional red blood cells. PLoS ONE, Vol. 3, No. 2, 2008) e1544, 1932-6203 (Electronic)

Ho, A.; Schwarze, S. R.; Mermelstein, S. J.; Waksman, G. \& Dowdy, S. F. (2001). Synthetic protein transduction domains: enhanced transduction potential in vitro and in vivo. Cancer Res, Vol. 61, No. 2, (Jan 15 2001) 474-477, 0008-5472 (Print) 0008-5472 (Linking)

Johansson, B. M. \& Wiles, M. V. (1995). Evidence for involvement of activin A and bone morphogenetic protein 4 in mammalian mesoderm and hematopoietic development. Mol Cell Biol, Vol. 15, No. 1, (Jan 1995) 141-151, 0270-7306 (Print) 0270-7306 (Linking)

Kaufman, D. S.; Hanson, E. T.; Lewis, R. L.; Auerbach, R. \& Thomson, J. A. (2001). Hematopoietic colony-forming cells derived from human embryonic stem cells. Proc Natl Acad Sci U S A, Vol. 98, No. 19, (Sep 11 2001) 10716-10721, 0027-8424 (Print) 0027-8424 (Linking)

Kerst, J. M.; de Haas, M.; van der Schoot, C. E.; Slaper-Cortenbach, I. C.; Kleijer, M.; von dem Borne, A. E. \& van Oers, R. H. (1993). Recombinant granulocyte colony-stimulating factor administration to healthy volunteers: induction of immunophenotypically and functionally altered neutrophils via an effect on myeloid progenitor cells. Blood, Vol. 82, No. 11, (Dec 1 1993) 3265-3272, 0006-4971 (Print) 0006-4971 (Linking)

Kerst, J. M.; van de Winkel, J. G.; Evans, A. H.; de Haas, M.; Slaper-Cortenbach, I. C.; de Wit, T. P.; von dem Borne, A. E.; van der Schoot, C. E. \& van Oers, R. H. (1993). Granulocyte colony-stimulating factor induces $\mathrm{hFc}$ gamma RI (CD64 antigen)positive neutrophils via an effect on myeloid precursor cells. Blood, Vol. 81, No. 6, (Mar 15 1993) 1457-1464, 0006-4971 (Print) 0006-4971 (Linking)

Kobayashi, T.; Yamaguchi, T.; Hamanaka, S.; Kato-Itoh, M.; Yamazaki, Y.; Ibata, M.; Sato, H.; Lee, Y. S.; Usui, J.; Knisely, A. S.; Hirabayashi, M. \& Nakauchi, H. (2010). Generation of rat pancreas in mouse by interspecific blastocyst injection of pluripotent stem cells. Cell, Vol. 142, No. 5, (Sep 3 2010) 787-799, 1097-4172 (Electronic) 0092-8674 (Linking)

Kumano, K.; Chiba, S.; Kunisato, A.; Sata, M.; Saito, T.; Nakagami-Yamaguchi, E.; Yamaguchi, T.; Masuda, S.; Shimizu, K.; Takahashi, T.; Ogawa, S.; Hamada, Y. \& Hirai, H. (2003). Notch1 but not Notch2 is essential for generating hematopoietic stem cells from endothelial cells. Immunity, Vol. 18, No. 5, (May 2003) 699-711, 10747613 (Print) 1074-7613 (Linking)

Kyba, M.; Perlingeiro, R. C. \& Daley, G. Q. (2002). HoxB4 confers definitive lymphoidmyeloid engraftment potential on embryonic stem cell and yolk sac hematopoietic progenitors. Cell, Vol. 109, No. 1, (Apr 5 2002) 29-37, 0092-8674 (Print) 0092-8674 (Linking)

Ledran, M. H.; Krassowska, A.; Armstrong, L.; Dimmick, I.; Renstrom, J.; Lang, R.; Yung, S.; Santibanez-Coref, M.; Dzierzak, E.; Stojkovic, M.; Oostendorp, R. A.; Forrester, L. \& Lako, M. (2008). Efficient hematopoietic differentiation of human embryonic stem cells on stromal cells derived from hematopoietic niches. Cell Stem Cell, Vol. 3, No. 1, (Jul 3 2008) 85-98, 1875-9777 (Electronic)

Lieber, J. G.; Webb, S.; Suratt, B. T.; Young, S. K.; Johnson, G. L.; Keller, G. M. \& Worthen, G. S. (2004). The in vitro production and characterization of neutrophils from embryonic stem cells. Blood, Vol. 103, No. 3, (Feb 1 2004) 852-859, 0006-4971 (Print) 0006-4971 (Linking) 
Lindenbaum, M. H. \& Grosveld, F. (1990). An in vitro globin gene switching model based on differentiated embryonic stem cells. Genes Dev, Vol. 4, No. 12A, (Dec 1990) 20752085, 0890-9369 (Print) 0890-9369 (Linking)

Ljunggren, H. G. \& Malmberg, K. J. (2007). Prospects for the use of NK cells in immunotherapy of human cancer. Nat Rev Immunol, Vol. 7, No. 5, (May 2007) 329339, 1474-1733 (Print) 1474-1733 (Linking)

Lu, S. J.; Feng, Q.; Caballero, S.; Chen, Y.; Moore, M. A.; Grant, M. B. \& Lanza, R. (2007). Generation of functional hemangioblasts from human embryonic stem cells. Nat Methods, Vol. 4, No. 6, (Jun 2007) 501-509, 1548-7091 (Print) 1548-7091 (Linking)

Lu, S. J.; Feng, Q.; Ivanova, Y.; Luo, C.; Li, T.; Li, F.; Honig, G. R. \& Lanza, R. (2007). Recombinant HoxB4 fusion proteins enhance hematopoietic differentiation of human embryonic stem cells. Stem Cells Dev, Vol. 16, No. 4, (Aug 2007) 547-559, 1547-3287 (Print) 1547-3287 (Linking)

Lu, S. J.; Feng, Q.; Park, J. S.; Vida, L.; Lee, B. S.; Strausbauch, M.; Wettstein, P. J.; Honig, G. R. \& Lanza, R. (2008). Biologic properties and enucleation of red blood cells from human embryonic stem cells. Blood, Vol. 112, No. 12, (Dec 1 2008) 4475-4484, 15280020 (Electronic) 0006-4971 (Linking)

Ma, F.; Wang, D.; Hanada, S.; Ebihara, Y.; Kawasaki, H.; Zaike, Y.; Heike, T.; Nakahata, T. \& Tsuji, K. (2007). Novel method for efficient production of multipotential hematopoietic progenitors from human embryonic stem cells. Int J Hematol, Vol. 85, No. 5, (Jun 2007) 371-379, 0925-5710 (Print) 0925-5710 (Linking)

Ma, F.; Ebihara, Y.; Umeda, K.; Sakai, H.; Hanada, S.; Zhang, H.; Zaike, Y.; Tsuchida, E.; Nakahata, T.; Nakauchi, H. \& Tsuji, K. (2008). Generation of functional erythrocytes from human embryonic stem cell-derived definitive hematopoiesis. Proc Natl Acad Sci U S A, Vol. 105, No. 35, (Sep 2 2008) 13087-13092, 1091-6490 (Electronic) 00278424 (Linking)

Martin, C. H.; Woll, P. S.; Ni, Z.; Zuniga-Pflucker, J. C. \& Kaufman, D. S. (2008). Differences in lymphocyte developmental potential between human embryonic stem cell and umbilical cord blood-derived hematopoietic progenitor cells. Blood, Vol. 112, No. 7, (Oct 1 2008) 2730-2737, 1528-0020 (Electronic) 0006-4971 (Linking)

Martin, G. R. (1981). Isolation of a pluripotent cell line from early mouse embryos cultured in medium conditioned by teratocarcinoma stem cells. Proc Natl Acad Sci U $S$ A, Vol. 78, No. 12, (Dec 1981) 7634-7638, 0027-8424 (Print) 0027-8424 (Linking)

McCune, J. M.; Namikawa, R.; Kaneshima, H.; Shultz, L. D.; Lieberman, M. \& Weissman, I. L. (1988). The SCID-hu mouse: murine model for the analysis of human hematolymphoid differentiation and function. Science, Vol. 241, No. 4873, (Sep 23 1988) 1632-1639, 0036-8075 (Print) 0036-8075 (Linking)

Miller, J. S.; Soignier, Y.; Panoskaltsis-Mortari, A.; McNearney, S. A.; Yun, G. H.; Fautsch, S. K.; McKenna, D.; Le, C.; Defor, T. E.; Burns, L. J.; Orchard, P. J.; Blazar, B. R.; Wagner, J. E.; Slungaard, A.; Weisdorf, D. J.; Okazaki, I. J. \& McGlave, P. B. (2005). Successful adoptive transfer and in vivo expansion of human haploidentical NK cells in patients with cancer. Blood, Vol. 105, No. 8, (Apr 15 2005) 3051-3057, 00064971 (Print) 0006-4971 (Linking)

Nakano, T.; Kodama, H. \& Honjo, T. (1994). Generation of lymphohematopoietic cells from embryonic stem cells in culture. Science, Vol. 265, No. 5175, (Aug 19 1994) 1098$1101,0036-8075$ 
Nakayama, N.; Lee, J. \& Chiu, L. (2000). Vascular endothelial growth factor synergistically enhances bone morphogenetic protein-4-dependent lymphohematopoietic cell generation from embryonic stem cells in vitro. Blood, Vol. 95, No. 7, (Apr 1 2000) 2275-2283, 0006-4971 (Print) 0006-4971 (Linking)

Nishikii, H.; Eto, K.; Tamura, N.; Hattori, K.; Heissig, B.; Kanaji, T.; Sawaguchi, A.; Goto, S.; Ware, J. \& Nakauchi, H. (2008). Metalloproteinase regulation improves in vitro generation of efficacious platelets from mouse embryonic stem cells. J Exp Med, Vol. 205, No. 8, (Aug 4 2008) 1917-1927, 1540-9538 (Electronic) 0022-1007 (Linking)

Okuda, T.; van Deursen, J.; Hiebert, S. W.; Grosveld, G. \& Downing, J. R. (1996). AML1, the target of multiple chromosomal translocations in human leukemia, is essential for normal fetal liver hematopoiesis. Cell, Vol. 84, No. 2, (Jan 26 1996) 321-330, 00928674 (Print) 0092-8674 (Linking)

Olivier, E. N.; Qiu, C.; Velho, M.; Hirsch, R. E. \& Bouhassira, E. E. (2006). Large-scale production of embryonic red blood cells from human embryonic stem cells. Exp Hematol, Vol. 34, No. 12, (Dec 2006) 1635-1642, 0301-472X (Print) 0301-472X (Linking)

Perlingeiro, R. C.; Kyba, M. \& Daley, G. Q. (2001). Clonal analysis of differentiating embryonic stem cells reveals a hematopoietic progenitor with primitive erythroid and adult lymphoid-myeloid potential. Development, Vol. 128, No. 22, (Nov 2001) 4597-4604, 0950-1991 (Print) 0950-1991 (Linking)

Peschle, C.; Mavilio, F.; Care, A.; Migliaccio, G.; Migliaccio, A. R.; Salvo, G.; Samoggia, P.; Petti, S.; Guerriero, R.; Marinucci, M. \& et al. (1985). Haemoglobin switching in human embryos: asynchrony of zeta----alpha and epsilon----gamma-globin switches in primitive and definite erythropoietic lineage. Nature, Vol. 313, No. 5999, (Jan 17-23 1985) 235-238, 0028-0836 (Print) 0028-0836 (Linking)

Porcher, C.; Swat, W.; Rockwell, K.; Fujiwara, Y.; Alt, F. W. \& Orkin, S. H. (1996). The T cell leukemia oncoprotein SCL/tal-1 is essential for development of all hematopoietic lineages. Cell, Vol. 86, No. 1, (Jul 12 1996) 47-57, 0092-8674 (Print) 0092-8674 (Linking)

Rado, T. A.; Bollekens, J.; St Laurent, G.; Parker, L. \& Benz, E. J., Jr. (1984). Lactoferrin biosynthesis during granulocytopoiesis. Blood, Vol. 64, No. 5, (Nov 1984) 1103-1109, 0006-4971 (Print) 0006-4971 (Linking)

Richardson, M. P.; Ayliffe, M. J.; Helbert, M. \& Davies, E. G. (1998). A simple flow cytometry assay using dihydrorhodamine for the measurement of the neutrophil respiratory burst in whole blood: comparison with the quantitative nitrobluetetrazolium test. $J$ Immunol Methods, Vol. 219, No. 1-2, (Oct 1 1998) 187-193, 0022-1759 (Print) 00221759 (Linking)

Ruggeri, L.; Capanni, M.; Urbani, E.; Perruccio, K.; Shlomchik, W. D.; Tosti, A.; Posati, S.; Rogaia, D.; Frassoni, F.; Aversa, F.; Martelli, M. F. \& Velardi, A. (2002). Effectiveness of donor natural killer cell alloreactivity in mismatched hematopoietic transplants. Science, Vol. 295, No. 5562, (Mar 15 2002) 2097-2100, 1095-9203 (Electronic) 0036-8075 (Linking)

Saeki, K.; Nakahara, M.; Matsuyama, S.; Nakamura, N.; Yogiashi, Y.; Yoneda, A.; Koyanagi, M.; Kondo, Y. \& Yuo, A. (2009). A feeder-free and efficient production of functional neutrophils from human embryonic stem cells. Stem Cells, Vol. 27, No. 1, (Jan 2009) 59-67, 1549-4918 (Electronic) 1066-5099 (Linking)

Schmitt, T. M.; de Pooter, R. F.; Gronski, M. A.; Cho, S. K.; Ohashi, P. S. \& Zuniga-Pflucker, J. C. (2004). Induction of T cell development and establishment of T cell competence 
from embryonic stem cells differentiated in vitro. Nat Immunol, Vol. 5, No. 4, (Apr 2004) 410-417, 1529-2908 (Print) 1529-2908 (Linking)

Slukvin, II; Vodyanik, M. A.; Thomson, J. A.; Gumenyuk, M. E. \& Choi, K. D. (2006). Directed differentiation of human embryonic stem cells into functional dendritic cells through the myeloid pathway. J Immunol, Vol. 176, No. 5, (Mar 1 2006) 29242932, 0022-1767 (Print) 0022-1767 (Linking)

Stadtfeld, M. \& Hochedlinger, K. (2010). Induced pluripotency: history, mechanisms, and applications. Genes Dev, Vol. 24, No. 20, (Oct 15 2010) 2239-2263, 1549-5477 (Electronic) 0890-9369 (Linking)

Suzuki, T.; Yokoyama, Y.; Kumano, K.; Takanashi, M.; Kozuma, S.; Takato, T.; Nakahata, T.; Nishikawa, M.; Sakano, S.; Kurokawa, M.; Ogawa, S. \& Chiba, S. (2006). Highly efficient ex vivo expansion of human hematopoietic stem cells using Delta1-Fc chimeric protein. Stem Cells, Vol. 24, No. 11, (Nov 2006) 2456-2465, 1066-5099 (Print) 1066-5099 (Linking)

Takahashi, K.; Tanabe, K.; Ohnuki, M.; Narita, M.; Ichisaka, T.; Tomoda, K. \& Yamanaka, S. (2007). Induction of pluripotent stem cells from adult human fibroblasts by defined factors. Cell, Vol. 131, No. 5, (Nov 30 2007) 861-872, 0092-8674

Takayama, N.; Nishikii, H.; Usui, J.; Tsukui, H.; Sawaguchi, A.; Hiroyama, T.; Eto, K. \& Nakauchi, H. (2008). Generation of functional platelets from human embryonic stem cells in vitro via ES-sacs, VEGF-promoted structures that concentrate hematopoietic progenitors. Blood, Vol. 111, No. 11, (Jun 1 2008) 5298-5306, 1528-0020 (Electronic) 0006-4971 (Linking)

Thomson, J. A.; Itskovitz-Eldor, J.; Shapiro, S. S.; Waknitz, M. A.; Swiergiel, J. J.; Marshall, V. S. \& Jones, J. M. (1998). Embryonic stem cell lines derived from human blastocysts. Science, Vol. 282, No. 5391, (Nov 6 1998) 1145-1147, 0036-8075

Tian, X.; Woll, P. S.; Morris, J. K.; Linehan, J. L. \& Kaufman, D. S. (2006). Hematopoietic engraftment of human embryonic stem cell-derived cells is regulated by recipient innate immunity. Stem Cells, Vol. 24, No. 5, (May 2006) 1370-1380, 1066-5099 (Print) 1066-5099 (Linking)

Timmermans, F.; Velghe, I.; Vanwalleghem, L.; De Smedt, M.; Van Coppernolle, S.; Taghon, T.; Moore, H. D.; Leclercq, G.; Langerak, A. W.; Kerre, T.; Plum, J. \& Vandekerckhove, B. (2009). Generation of T cells from human embryonic stem cellderived hematopoietic zones. J Immunol, Vol. 182, No. 11, (Jun 1 2009) 6879-6888, 1550-6606 (Electronic) 0022-1767 (Linking)

Tsai, F. Y.; Keller, G.; Kuo, F. C.; Weiss, M.; Chen, J.; Rosenblatt, M.; Alt, F. W. \& Orkin, S. H. (1994). An early haematopoietic defect in mice lacking the transcription factor GATA-2. Nature, Vol. 371, No. 6494, (Sep 15 1994) 221-226, 0028-0836 (Print) 00280836 (Linking)

Ueda, T.; Tsuji, K.; Yoshino, H.; Ebihara, Y.; Yagasaki, H.; Hisakawa, H.; Mitsui, T.; Manabe, A.; Tanaka, R.; Kobayashi, K.; Ito, M.; Yasukawa, K. \& Nakahata, T. (2000). Expansion of human NOD/SCID-repopulating cells by stem cell factor, Flk2/Flt3 ligand, thrombopoietin, IL-6, and soluble IL-6 receptor. J Clin Invest, Vol. 105, No. 7, (Apr 2000) 1013-1021, 0021-9738 (Print) 0021-9738 (Linking)

van de Winkel, J. G. \& Anderson, C. L. (1991). Biology of human immunoglobulin G Fc receptors. J Leukoc Biol, Vol. 49, No. 5, (May 1991) 511-524, 0741-5400 (Print) 07415400 (Linking) 
van Lochem, E. G.; van der Velden, V. H.; Wind, H. K.; te Marvelde, J. G.; Westerdaal, N. A. \& van Dongen, J. J. (2004). Immunophenotypic differentiation patterns of normal hematopoiesis in human bone marrow: reference patterns for age-related changes and disease-induced shifts. Cytometry B Clin Cytom, Vol. 60, No. 1, (Jul 2004) 1-13, 1552-4949 (Print) 1552-4949 (Linking)

Vodyanik, M. A.; Bork, J. A.; Thomson, J. A. \& Slukvin, II. (2005). Human embryonic stem cell-derived CD34+ cells: efficient production in the coculture with OP9 stromal cells and analysis of lymphohematopoietic potential. Blood, Vol. 105, No. 2, (Jan 15 2005) 617-626, 0006-4971 (Print) 0006-4971 (Linking)

Wang, L.; Li, L.; Shojaei, F.; Levac, K.; Cerdan, C.; Menendez, P.; Martin, T.; Rouleau, A. \& Bhatia, M. (2004). Endothelial and hematopoietic cell fate of human embryonic stem cells originates from primitive endothelium with hemangioblastic properties. Immunity, Vol. 21, No. 1, (Jul 2004) 31-41, 1074-7613 (Print) 1074-7613 (Linking)

Wang, L.; Menendez, P.; Shojaei, F.; Li, L.; Mazurier, F.; Dick, J. E.; Cerdan, C.; Levac, K. \& Bhatia, M. (2005). Generation of hematopoietic repopulating cells from human embryonic stem cells independent of ectopic HOXB4 expression. J Exp Med, Vol. 201, No. 10, (May 16 2005) 1603-1614, 0022-1007 (Print) 0022-1007 (Linking)

Weisel, K. C.; Gao, Y.; Shieh, J. H. \& Moore, M. A. (2006). Stromal cell lines from the aortagonado-mesonephros region are potent supporters of murine and human hematopoiesis. Exp Hematol, Vol. 34, No. 11, (Nov 2006) 1505-1516, 0301-472X (Print) 0301-472X (Linking)

Wiles, M. V. \& Keller, G. (1991). Multiple hematopoietic lineages develop from embryonic stem (ES) cells in culture. Development, Vol. 111, No. 2, (Feb 1991) 259-267, 09501991 (Print) 0950-1991 (Linking)

Woll, P. S.; Martin, C. H.; Miller, J. S. \& Kaufman, D. S. (2005). Human embryonic stem cellderived NK cells acquire functional receptors and cytolytic activity. J Immunol, Vol. 175, No. 8, (Oct 15 2005) 5095-5103, 0022-1767 (Print) 0022-1767 (Linking)

Woll, P. S.; Grzywacz, B.; Tian, X.; Marcus, R. K.; Knorr, D. A.; Verneris, M. R. \& Kaufman, D. S. (2009). Human embryonic stem cells differentiate into a homogeneous population of natural killer cells with potent in vivo antitumor activity. Blood, Vol. 113, No. 24, (Jun 11 2009) 6094-6101, 1528-0020 (Electronic) 0006-4971 (Linking)

Yamane, T.; Hosen, N.; Yamazaki, H. \& Weissman, I. L. (2009). Expression of AA4.1 marks lymphohematopoietic progenitors in early mouse development. Proc Natl Acad Sci U S A, Vol. 106, No. 22, (Jun 2 2009) 8953-8958, 1091-6490 (Electronic) 0027-8424 (Linking)

Ying, Q. L.; Stavridis, M.; Griffiths, D.; Li, M. \& Smith, A. (2003). Conversion of embryonic stem cells into neuroectodermal precursors in adherent monoculture. Nat Biotechnol, Vol. 21, No. 2, (Feb 2003) 183-186, 1087-0156 (Print) 1087-0156 (Linking)

Yokoyama, Y.; Suzuki, T.; Sakata-Yanagimoto, M.; Kumano, K.; Higashi, K.; Takato, T.; Kurokawa, M.; Ogawa, S. \& Chiba, S. (2009). Derivation of functional mature neutrophils from human embryonic stem cells. Blood, Vol. 113, No. 26, (Jun 25 2009) 6584-6592, 1528-0020 (Electronic) 0006-4971 (Linking)

Zou, G. M.; Chen, J. J.; Yoder, M. C.; Wu, W. \& Rowley, J. D. (2005). Knockdown of Pu.1 by small interfering RNA in CD34+ embryoid body cells derived from mouse ES cells turns cell fate determination to pro-B cells. Proc Natl Acad Sci U S A, Vol. 102, No. 37, (Sep 13 2005) 13236-13241, 0027-8424 (Print) 0027-8424 (Linking) 


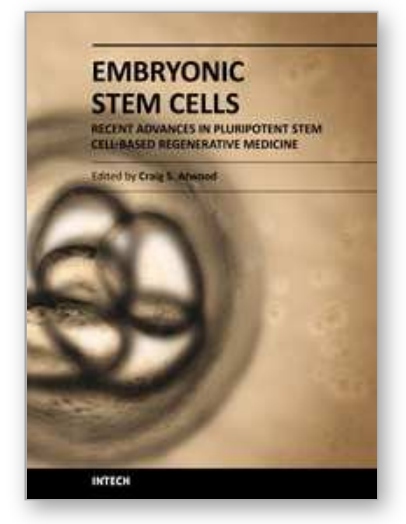

\section{Embryonic Stem Cells - Recent Advances in Pluripotent Stem Cell- Based Regenerative Medicine}

Edited by Prof. Craig Atwood

ISBN 978-953-307-198-5

Hard cover, 410 pages

Publisher InTech

Published online 26, April, 2011

Published in print edition April, 2011

Pluripotent stem cells have the potential to revolutionise medicine, providing treatment options for a wide range of diseases and conditions that currently lack therapies or cures. This book describes recent advances in the generation of tissue specific cell types for regenerative applications, as well as the obstacles that need to be overcome in order to recognize the potential of these cells.

\section{How to reference}

In order to correctly reference this scholarly work, feel free to copy and paste the following:

Yasuhisa Yokoyama, Hidekazu Nishikii and Shigeru Chiba (2011). Hematopoietic Differentiation from Embryonic Stem Cells, Embryonic Stem Cells - Recent Advances in Pluripotent Stem Cell-Based Regenerative Medicine, Prof. Craig Atwood (Ed.), ISBN: 978-953-307-198-5, InTech, Available from:

http://www.intechopen.com/books/embryonic-stem-cells-recent-advances-in-pluripotent-stem-cell-basedregenerative-medicine/hematopoietic-differentiation-from-embryonic-stem-cells

\section{INTECH}

open science | open minds

\author{
InTech Europe \\ University Campus STeP Ri \\ Slavka Krautzeka 83/A \\ 51000 Rijeka, Croatia \\ Phone: +385 (51) 770447 \\ Fax: +385 (51) 686166 \\ www.intechopen.com
}

\author{
InTech China \\ Unit 405, Office Block, Hotel Equatorial Shanghai \\ No.65, Yan An Road (West), Shanghai, 200040, China \\ 中国上海市延安西路65号上海国际贵都大饭店办公楼 405 单元 \\ Phone: +86-21-62489820 \\ Fax: $+86-21-62489821$
}


(C) 2011 The Author(s). Licensee IntechOpen. This chapter is distributed under the terms of the Creative Commons Attribution-NonCommercialShareAlike-3.0 License, which permits use, distribution and reproduction for non-commercial purposes, provided the original is properly cited and derivative works building on this content are distributed under the same license. 